\title{
The French Revolution Collection
}

\author{
MARCIA A N H A B BLD
}

The Library of The University of Iowa offers the scholar a wellbalanced, working collection of primary materials on the French Revolution. Although it is not the most outstanding collection of its kind in the United States, it provides an excellent starting point for scholarly research in this era. Available to students in the Government Documents department of the Library are the Archives Parlementaires de 1787 a 1860 (Paris: Dupont, 1903- ), of which volumes 1 to 82, 1787 to January 4, 1794 are on the revolutionary period; the Collection de documents inédits sur l'histoire de France ... (Paris: Imp. nationale, 1835- ) in 127 volumes of which volumes 64 to 70 cover the Revolution; Actes de la Commune de Paris pendant la révolution, 1789-1794 (Paris: Lacroix, 1894- ) in sixteen volumes; Aulard's La Société des Jacobins, Recueil de documents pour lhistoire du club des Jacobins de Paris (Paris: Librairie Jouaust, etc. 1889-97) in six volumes; and, finally, Recueil des actes du Comité de salut public, avec la correspondance officielle des représentants en mission . . . (Paris: Imp. nationale, 1889-1925), of which we have volumes 1-20 and 22-24. These are all basic primary sources for the study of the period. In addition, the library has a number of the major bibliographical aids to research, including Alexandre Tuetey's Repertoire général des sources manuscrites de l'histoire de Paris pendant la révolution française (Paris: Imp. nouvelle, 1890-1914) in eleven volumes.

Necessary to an understanding of the Revolution itself is a substantial knowledge of conditions in France before 1789. Following are the sources on the subject included in the collection: the Procés-verbaux (official records) of several provincial assemblies-Berri, 1783 and 1786; Basse-Normandie, 1787; Haute-Guienne, 1786; Isle de France, 1787; Soissons, 1787; reports of deliberations of local assemblies of Provence in thirteen volumes covering the years 1681 to 
1789; celebrated judicial cases and decisions published from 1739 to 1750 in twenty volumes; a miscellaneous collection of decrees and proceedings of the Parlements, which were the French supreme courts of appeal for civil and criminal cases; and Controller-General of Finance Necker's famous report to King Louis XVI in 1781. Another essential source housed in the Government Documents department is the Procès-verbaux de l'assemblée nationale (Paris: Baudouin, 1789- ). This is the official record of the National Constituent Assembly and begins with the session of June 17, 1789, at which the French commoners and their clerical supporters perpetrated the first act of the Revolution by declaring themselves the National Assembly of France and proceeding to act as the representative body of the nation. We have all but a few of the issues from June 17, 1789 through September 30,1791 .

Newspapers constitute a chief source of information on the Revolutionary period, for in France political journalism may be said to have begun with the Revolution. Here again the library's collection provides a good starting point for research. Although the later years of the revolutionary period from 1794 to 1799 are not strongly represented, the early years, 1789 to 1793 , are treated most adequately in these papers. Not only is the famous Le Monteur universel complete for the Revolution, but there are just a few numbers missing in its files (184 vols.) from the first issue in 1789 down to 1868 . We have also one of the few complete sets of the Comte de Mirabeau's well-known journal, Le Courrier de Provence in seventeen volumes, including the first two numbers of his paper entitled Etats-Generaux which were suppressed by a decree of the Council of State on May 7, 1789.

Space permits only the briefest mention of the other available papers: Richer Serisy's L'Accusateur public (1793-97); the royalist Les Actes des apôtres (1789-91), founded by Jean-Gabrile Peltier; Journal de Paris (1788-93); Clavière and Condorcet's La Chronique du mois (1791-93); and among the more influential revolutionary newspapers, Desmoulin's Le Vieux cordelier (Dec. 5, 1793-Feb. 3, 1794) and Revolutions de France et de Brabant (Nos. 1-4, 1789); Hébert's Le Père Duchêne (Sept. 1790-Feb. 12, 1791); Marat's L'Ami du peuple (Sept. 12-Oct. 8, 1789; and Prudhomme's Révolutions de Paris (1789-94). The library possesses a nearly complete set of the extremely rare $\mathrm{Ga}$ zette de Leyde from 1773 to 1811 . Thus, this paper covers the period of the American Revolution, the French Revolution, and most of the Napoleonic era.

The materials so far described constitute part of the library's general collection on the French Revolution. In addition to these holdings, 
the Special Collections department houses a valuable pamphlet collection of over 8,000 pieces which can be considered the nucleus of the library's French Revolution holdings. This pamphlet material was principally acquired in four separate purchases which are now being integrated. The first section (consisting of two purchases) comprises a collection of about 2,000 pamphlets-mostly political tracts and polemical pieces-now bound together in seventy-six volumes. The library purchased these in 1930 from an antiquary in Berlin named Altmann. Previously, a Dr. Linson of Berlin had owned the pamphlets. The library purchased the second section of pamphlets in about 1960 from the bookseller Nijhoff at The Hague in the Netherlands. This section comprises more than 5,500 pamphlets, laws, and tracts. Approximately 550 unbound pieces-informative and polemical pamphlets, laws and proceedings of assemblies, and miscellaneous issues of journals-make up the third section of pamphlets which are currently being catalogued.

Although the collection was acquired in several sections, these actually form an integrated body of material on the period of the French Revolution. The bulk of the collection covers the period from about 1788 to 1799 , though later years are also represented. Included is an extremely comprehensive range of subjects, running the gamut from a piece on the conservation of honey bees, an advertisement for Burgundian wines, a public notice concerning an unsuccessful physics experiment, and a message to the National Assembly on the interests of French artists to such weighty matters of state as the condition of finances and the meeting of the Estates General at Versailles in May, 1789. Some of the subjects especially well represented in the collection might be of interest: numerous aspects of the French Army during the Revolutionary Wars; the activities of the Estates General, the National Constituent Assembly (1789-91), and the National Convention (1792-95); financial problems and attempts at fiscal reform, including material on the assignats, which was the paper money issued by the Revolutionary Government from 1790 until 1796; events and conditions in the provinces, especially in the coastal province of Brittany; a number of pamphlets relating to Paris during the Revolution; the monumental issue of church-state relations, notably the strife over the Civil Constitution of the Clergy (July, 1790) and the civil oath required of the clergy. The former measure transformed religious functions into civic duties, thus rendering the Church subordinate to the French state. On this issue there is a Papal brief dated March 10, 1791, from Pope Pius VI to the Archbishop of Aix and to all the other archbishops and bishops of the National Assembly in which the Pope 
denounces not only the Civil Constitution but all the other anti-religious enactments of the Assembly. Such papal action cut France in two: it forced the clergy to choose openly between nation and church. Thus, instead of creating a national church, the deputies had succeeded only in creating two hostile churches-one for the adherents of the revolutionary government and one for those forced into the position of opponents of the Revolution and all its works. This dichotomy characterized French life for more than a century after the Revolution. Viewed in this light, the gravity of the issue and of Pius VI's brief becomes apparent.

Another event of the Revolution illuminated by these contemporary sources is the trial and execution of Louis XVI. On August 10, 1792, as the result of evidence attesting to his treasonable activities, Louis was suspended and he and his family were imprisoned. At the first session of the National Convention in September, the deputies passed a unanimous decree abolishing the monarchy. Responding to popular sentiment for Louis's punishment, the committee on legislation then decided that the former king was not inviolable and could be tried as a private citizen. Louis's trial lingered on for more than a month, and despite last-minute attempts to save him, the king was guillotined on Sunday, January 21, 1793. Of course this crucial episode induced the pamphleteers to express their opinions, and they did so vigorously. Our collection includes about thirty to forty polemical pamphlets penned by both the defenders and the detractors of the king, along with articles in the journals and newspapers of the period, and fifteen or twenty pieces on the voting and official proceedings. These sources comprise what is probably a good cross section of the materials on this issue available in the United States.

The French Revolution pamphlet collection provides an interesting sample of the range of literary forms used by the pamphleteer of the late eighteenth century. In addition to the political essay, writers expressed their ideas in verse, songs, dramas, dialogues and didactic narratives, many of which were satirical in tone. Even liturgical forms such as the Paternoster, Dies Irae, and Credo were adapted to the needs of political debate. The trial and execution of Louis XVI was the subject of a drama written by an anonymous royalist. He entitled his masterpiece of patriotic sentiment La Mort de Louis seize, a tragedy in three acts.

Finally, the collection contains numerous pamphlets written by most of the famous and many of the lesser-known figures who played a role in the Revolution. This list, though not complete, gives the approximate number of pieces authored by each in parentheses after the in- 
dividual's name. Bailly (5) the mayor of Paris, 1789-91; the dramatist Beaumarchais (2); Brissot (30); Calonne (7) controller-general of finances, 1783-87; the apostate Prussian baron Anacharsis Cloots (2); the fiery journalist Camille Desmoulins (10); the Abbe Gregoire (15); Jean Paul Marat (6); Mirabeau (50); Necker (35); Robespierre (12); the Abbe Sieyes (20); Talleyrand (15); Voltaire (2); and the members of the Committee of Public Safety are all represented, along with other spokesmen both for and against the French Revolution. Thus, it can be said that Iowa's French Revolution collection offers a comprehensive selection of materials-some of which are indispensable and all of which are useful-to the student of the French Revolution. 


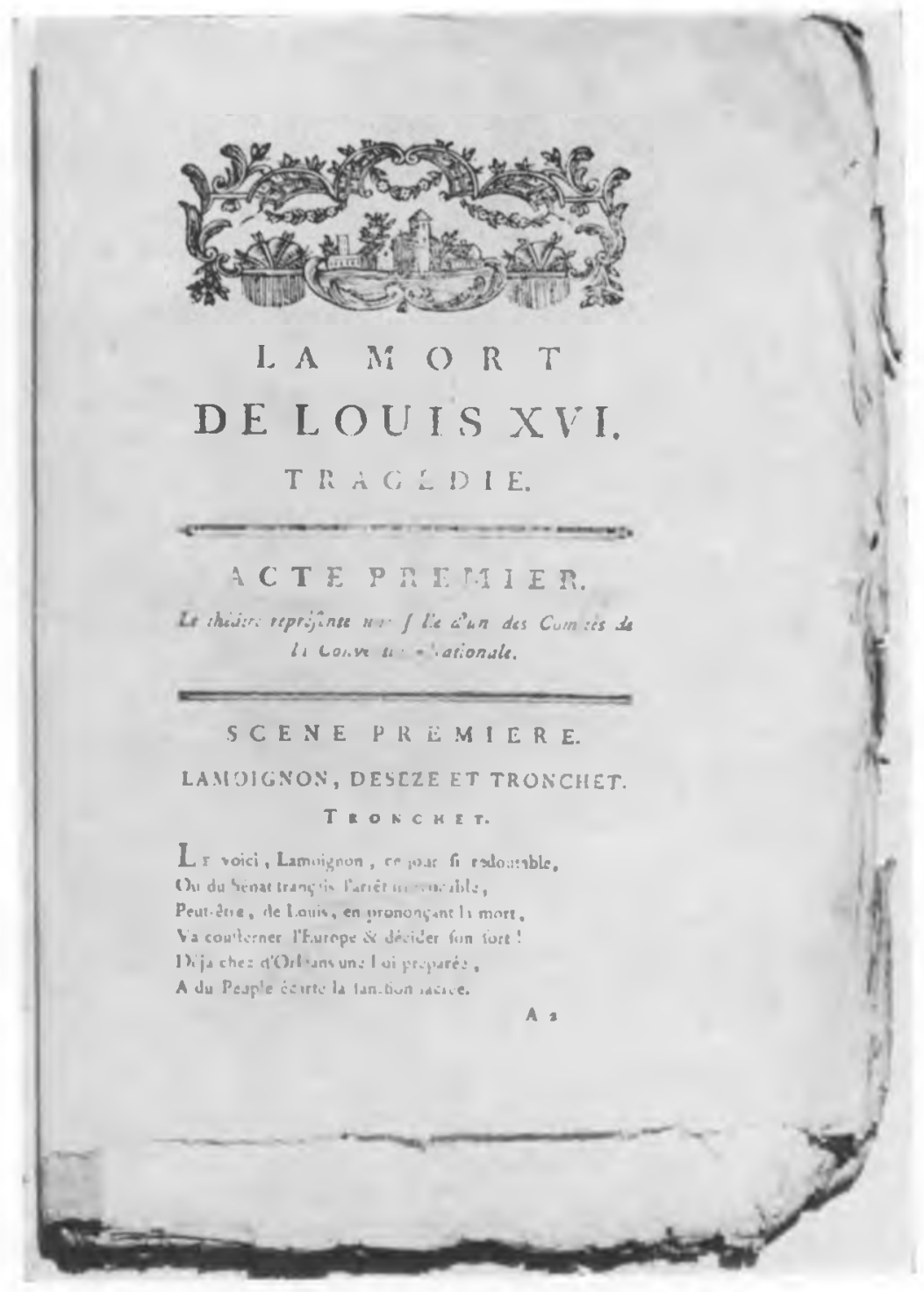

Opening lines of a three-act tragedy on the execution of Louis XVI, written by an anonymous royalist. 